\title{
A STABIL KORMÁNYZÁS FELTÉTELEINEK ALAPVETŐ VÁLTOZÁSA A 2010-ES ÉVEKBEN SPANYOLORSZÁGBAN
}

\author{
The Fundamental Changes of the Conditions of the \\ Government Stability in the 2010s in Spain
}

\section{Tóth László ${ }^{1}$}

\begin{abstract}
Absztrakt: 2020 januárjában a modern kori (azaz Francisco Franco tábornok 1975-ben bekövetkezett halála utáni) Spanyolországban először alakult koalíciós kormány. Az országban újszerû formátumúnak számító kormány beiktatása egy több, mint másfél éves válságperiódust hivatott lezárni, tágabban nézve azonban az instabilitás már 2015 decembere óta jelen volt. A spanyolországi demokráciát a hetvenes évek végétől viszonylag stabil kormányzás jellemezte, ahol mindig egypárti kormányok múködtek, és minden kormány lehetőséget kapott a több cikluson keresztül történő kormányzásra. Ez a helyzet változott meg 2015 után, lényegében folyamatos instabilitást és kormányválságokat eredményezve. 2019. november 10-én négy éven belül immár negyedszer szólították az urnákhoz a spanyolországi választópolgárokat, hogy döntsenek a nemzeti törvényhozás két házának tagjairól, közvetve pedig természetesen az országot irányító kormány összetételéről. A tanulmány a kormányzati stabilitást vizsgáló szakirodalom megközelítésmódja és eszközkészlete segítségével azt tekinti át, mi okozta az ibériai országban a korábban viszonylag stabilnak tekinthetô rendszer megrendülését, a permanens kormányzati instabilitást.
\end{abstract}

Kulcsszavak: Spanyolország, kormányzat, stabilitás, kormányzati rendszer, pártrendszerek átalakulása

\footnotetext{
${ }^{1}$ Eötvös Loránd Tudományegyetem, Politikatudományi Doktori Iskola, PhD hallgató. Email címe: tothhlaszlo@gmail.com

A szerző további munkásságát lásd a Magyar Tudományos Művek Tára oldalán: https: $/ / \mathrm{m} 2 . \mathrm{mtmt}$. hu $/$ gui2 $/$ ?type $=$ authors\&mode $=$ browse\&sel $=10057218$
} 
Abstract: In January 2020, a coalition government was formed for the first time in modern (post-Franco) Spain. The investiture of the government in this novel format probably closed a 1.5 -year period of government crisis. However, this crisis period has lasted since the general election in December 2015. The Spanish democracy has had relatively stable governments since the end of 1970s. All of the cabinets in the country were one-party governments and all of them had the chance to govern for/through multiple terms of parliament. This situation changed dramatically after 2015. Since then continuous instability and several government crises has characterized the country, no government could fulfil its original mandate. On 10 November 2019, the fourth general election took place in a four-year period in Spain. The citizens of Spain elected the members of the two houses of parliament and evidently indirectly decided about the composition of government. This paper examines the reasons of the changing patterns of government stability in Spain using the approaches of the international literature of this research field in political science.

Keywords: Spain, government, stability, government system, transformation of party systems

\section{BEVEZETÉS}

2020. január 13-án a modern kori spanyol történelem folyamán elsőként alakult koalíciós kormány országos szinten. Pedro Sánchez második, kisebbségi koalíciós (PSOE-Podemos) kormánya mindenképpen mérföldkőnek tekinthető az ország politikai életében, ez a helyzet azonban egy Európa-szerte jelen lévő tendenciába illeszkedik. A kétezres évek második felétől kezdve érzékelhető egy átfogó európai tendencia a kormányzati instabilitás növekedése tekintetében. Ez - föleg a 2008-ban kirobbant globális pénzügyi és gazdasági válság után - a korábban a rendszereket domináló pártok visszaszorulásával, új, elitkritikus erők megjelenésével, és egy általános bizonytalanság-növekedéssel járt együtt Európa-szerte. Ennek sorába illeszthető be a 2010-es évek spanyolországi eseménysora, hiszen itt is megtalálhatók a főbb szimptómái a destabilizálódásnak (érintettség a gazdasági válságban, korábban domináns pártok visszaszorulása, válsága, új, elitkritikus erők megjelenése és áttörése). Spanyolország lényegében 2015 decembere óta, de különösen a 2019-es két általános választás eredményei alapján kiváló példa annak bemutatására, 
hogy a politikatudományi szakirodalomban általánosan elfogadott, a kormányzati stabilitást befolyásoló tényezők miként fejtik ki hatásukat, kombinációjuk miként hat a kormányokra és stabilitásukra. Ennek oka, hogy ebben az országban a stabilitást befolyásoló tényezők jelentős részének hatása explicit módon jelen van a politikai rendszerben, lehetôvé téve a komplex vizsgálatot.

Jelen tanulmány célja, hogy bemutassa, Spanyolország esetében miként fejtik ki hatásukat a kormányzati stabilitást befolyásoló tényezők, miként alakultak ezek a demokratizálódás, és fooként a nyolcvanas évek második fele után (utóbbi egy kifejezetten stabilnak tekinthető korszak kezdete volt, amely nagyjából 2015-ig tartott), majd miként következett be ezen tényezők egy részében változás, amely befolyásolta ezek kölcsönhatását, és a következményt, az évtizedek óta első koalíciós kormány létrejöttét is.

A dolgozat által vizsgált időszak lezárása a 2019. novemberi választás politikai szempontból értelmezhető végeredményéhez kötődik. Ez pedig a koalíciós, második Sánchez-kormány megalakulása 2020 januárjában. ${ }^{2}$

\section{A KORMÁNYZATI STABILITÁS FOGALMA, A STABILITÁSRA HATÓ VÁLTOZÓK}

Kormányzati stabilitáson alapvetően az egyes kormányok képességét értjük arra, hogy kitöltsék az eredetileg meghatározott mandátumukat, ${ }^{3}$ de a kormányzati stabilitás tárgykörébe tartozik az is, hogy egy választást (legyen az „rendes”, vagy előrehozott) követően miként képes reguláris kormány alakulni. A kormányalakítás folyamata, gyorsasága, az abban részt vevő szereplők és a felmerülő problémák köre ráadásul a kormány későbbi stabilitására, mandátumának várható hosszára is hatással van. Az itt is vizsgált spanyolországi szituáció pontosan erre a problémakörre szolgál példaként.

Ennek következtében tehát a kormányzati stabilitás komplex fogalomkör, vizsgálatakor figyelembe kell venni mind a kormányalakítás

${ }^{2}$ Jelen kézirat lezárásakor már több hete tart a COVID-19 világjárvány, melyben az egyik leginkább érintett ország Spanyolország. A dolgozat azonban nem kíván a járvány minden bizonnyal politikai színtéren is érvényesülő következményeire kitérni, ezért zárul a koalíciós kormány megalakulásánál a vizsgált időkeret.

3 TÓTH, 2018. 741.o. 
körülményeit, mind pedig az adott kormány helyzetét a politikai, és szűkebb értelemben véve intézményrendszeren belül.

A politikatudományban az elmúlt negyven-ötven évben született munkák alapján a következő tényezők befolyásolják a kormányzati stabilitást az egyes politikai rendszerekben: intézményes viszonyok, pártrendszerek, választási rendszerek. ${ }^{4}$ Utóbbit két okból szükséges az intézményrendszerből kiemelve, külön vizsgálni. Egyrészt, a választási rendszerek teremtenek kapcsolatot a politikai rendszer statikus (azaz állandó) elemei intézményrendszer - és a változó, változékony elemek (pártok, pártviszonyok) között. Másrészt a választási rendszerek hatása a kormányzati stabilitásra lehet olyan jelentôs (mint ahogy a spanyol példa kapcsán látni fogjuk), hogy az mindenképp önálló vizsgálatát igényli.

\subsection{A KORMÁNYZATI STABILITÁST BEFOLYÁSOLÓ INTÉZMÉNYES VÁLTOZÓK ${ }^{5}$}

A nemzetközi szakirodalom egyik oldalról az intézményes viszonyok főbb jellegzetességeit vizsgálja a kormányzati stabilitásra való hatásuk kapcsán. A különböző megközelítéseket szintetizálva az alábbi kategóriák vizsgálandók:

- kormányforma, az államfő szerepe a kormány kinevezésében és menesztésében,

- törvényhozás szerkezete, egy esetleges második kamara szerepe a kormányalakításban, a kormány ellenőrzésében,

- törvényhozás-végrehajtás viszonyrendszer:

- Szükséges-e a kormány formális invesztitúrája, az elvárt többség mértéke?

- Bizalmatlanság kifejezésének módja, benyújtók köre, szükséges szavazatarányok.

- Ki jogosult törvényhozás feloszlatására, milyen feltételekkel?

4 TóTH, 2018. 741-742, ill. Warwick, 1994. 11.o.

5 TÓTH, 2018. 750.o. 


\subsection{A VÁLASZTÁSI RENDSZER HATÁSAI ${ }^{6}$}

A választási rendszerek konvertálják a leadott szavazatokat mandátumokká, befolyásolva ezzel a törvényhozások összetételét, illetve a pártrendszerek fejlődéseit. A nemzetközi szakirodalom által általában vizsgált kategóriákat leegyszerűsítve a következő öt tényező mentén vizsgálható ez a mechanizmus:

- A választási rendszer alapvető formulája, azaz többségi, vegyes, vagy arányos rendszerrôl beszélünk-e,

- mandátumelosztás módja,

- választási körzetek beosztása, körzetek magnitúdója,

- jogi küszöb megléte, mértéke,

- jelöltállítás feltételei.

\subsection{A PÁRTRENDSZEREK VIZSGÁLT ATTRIBÚTUMAI ${ }^{7}$}

A pártrendszerek alább vizsgált jellegzetességei egyrészt az elméleti irodalomban is rendre előforduló jellemzők, másrészt pedig - a pártok fluktuációja - kifejezetten az új demokráciák, vagy átalakuló pártrendszerek vizsgálatához nyújtanak segítséget:

- pártok száma,

- versengés struktúrája,

- polarizáltság,

- a pártrendszer alapjait jelentő törésvonalak,

- pártverseny nyílt, vagy zárt jellege, blokkosodás a pártrendszerben,

- pártok fluktuációja a törvényhozási ciklusok között és ciklusok közben.

\subsection{MÓDSZERTAN}

A tanulmány a fenti alfejezetben bemutatott változók alapján röviden jellemzi a spanyolországi rendszert, majd történeti összehasonlító módszerrel mutatja be a 2015 decembere óta eltelt időszak fontos, a téma kapcsán releváns eseményeit a spanyol belpolitikában. Az egyes vizsgált

\footnotetext{
${ }^{6}$ A szerző saját, disszertációjában alkalmazott kategória-rendszere.

${ }^{7}$ A szerző saját, disszertációjában is alkalmazott kritérium-rendszere.
} 
változók alakulása kapcsán a korábbiakhoz képest bekövetkező változások azonosíthatók az instabilitást okozó fó tényezőkként.

\section{SPANYOLORSZÁG A KORMÁNYZATI STABILITÁST BEFOLYÁSOLÓ VÁLTOZÓK TÜKRÉBEN}

\subsection{INTÉZMÉNYES VISZONYOK}

Spanyolország parlamentáris monarchia, ebből, illetve az európai szokásokból következően az államfő döntően szimbolikus szerepkörrel rendelkezik, a kormányzati stabilitást befolyásoló tényezők közé nem számítható. Részben ennek is köszönhető, hogy a kormányforma egyértelműen parlamentáris rendszer.

Spanyolország területi beosztását tekintve ún. „regionális berendezkedésư" államnak tekinthető, ami köztes állapot az unitárius és föderatív rendszerek között. 17 autonóm közösség (röviden régió) alkotja, ${ }^{8}$ ezeknek önálló törvényhozó és végrehajtó szerveik vannak. Mégsem tekinthető föderatív államnak, ${ }^{9}$ mivel a régiók autonómiája az alkotmány alapján az országos, nemzeti szinttől eredeztethetô - és ez vissza is vonható. A regionális berendezkedésnek - tekintettel a fent említett régiós törvényhozó és végrehajtó szervekre, valamint az ennek folyományaként létező regionális szintû választásokra - politikai természetű következményei is vannak a kormányzati stabilitásra nézve, nevezetesen, bizonyos speciális történelmi fejlődésű régiókban regionális szintű pártrendszerek jöttek létre.

Spanyolországban a demokratizálódás óta részben a történelmi hagyományoknak is megfelelően kétkamarás törvényhozás múködik. A rendszer aszimmetrikus bikameralizmusnak tekinthetô, az alsóház (spanyol elnevezés: Congreso, magyar nyelven: Kongresszus) egyértelmú dominanciájával. ${ }^{10}$ A felsőház, a Szenátus a kormányalakításba egyáltalán nem avatkozhat be, a kormány kizárólag a Kongresszusnak felelős, a felsôház a kormányzat munkáját indirekt módon, felülszavazható ${ }^{11}$ vétójogával befolyásolhatja. Utóbbinak érvényesülését csökkenti, hogy a szenátorok

\footnotetext{
${ }^{8}$ HeBBERT, 1987. 247-248.o.

${ }^{9}$ GALlagher-LAVER-MAIR, 2011. 179.o.

10 AJENJo, 2015. 156.o.

11 A képviselők abszolút többségének szavazatával.
} 
többségét egyszerre választják a képviselőkkel, ${ }^{12}$ és mivel a választási rendszer az alsóházhoz képest is többségibb logikát követ, ${ }^{13}$ ezáltal többnyire megerősíti az ott tapasztalt erőviszonyokat.

\subsubsection{TÖRVÉNYHOZÁS-VÉGREHAJTÁS VISZONYRENDSZER}

Spanyolország alkotmánya megköveteli a kormány formális parlamenti invesztitúráját. Spanyolországban a kormányfó választással kerül hivatalába. A király (a választási eredmények és a Kongresszus összetételének figyelembe vételével kiválasztott) jelöltjének az első beiktatási (invesztitúra) szavazásán bírnia kell a Kongresszus képviselői abszolút többségének támogatását. Amennyiben ezt nem kapja meg, második fordulóra kerül sor, itt elegendő a relatív többség elérése. ${ }^{14} \mathrm{Ez}$ formálisan is lehetőséget biztosít kisebbségi kormány alakítására, a kormány külső támogatására, akár a szavazási procedúrától való távolmaradás segítségével. Amennyiben másodjára sem sikerül kormányfőt választani, akkor az uralkodó feloszlathatja a parlamentet.

Spanyolországban a kormány mint testület mandátuma a miniszterelnök személyéhez kötődik, a minisztereket az ő javaslatára nevezik ki és hívják vissza, a kormány összetételének alakítására a törvényhozásnak nincs lehetősége. Ez kiemeli a miniszterelnök szerepét, politológiai értelemben pedig elősegíti a végrehajtó hatalom prezidencializációját, legalábbis az intézményes feltételek tekintetében. ${ }^{15}$

Szintén a kormányfőt erősítő és a stabilitást biztosítani szándékolt eszköz a konstruktív bizalmatlansági indítvány intézménye. ${ }^{16}$ A konstruktív bizalmatlansági indítvány lényege, hogy csak akkor tekinthető elfogadottnak, ha az abszolút többséggel megszavazott indítványban az új miniszterelnök személyét is megjelölik, aki ezzel az aktussal megválasztottá válik. Ennek célja, hogy ne legyen „interregnum” a kormányok között, legalábbis azon esetekben, amikor kívülről buktatják meg a kormányt. Elvileg ez az intézmény nagyon megnehezíti az ellenzék részéről történő kormánybuktatást, lényegében kimondható, hogy a jogrendbe ültetésének célja az

\footnotetext{
12 Erre jogi kötöttség nincsen, azonban a szokásjog alapján eddig minden alkalommal egyszerre oszlatták fel a két kamarát, illetve egyidejűleg választották őket.

${ }^{13}$ HOPKIN, 2009. 377.o.

14 AJENJO, 2015. 156-157.o.

15 VAN BIEZEN-HOPKIN, 2005. 108-109.o.

16 VAN BIEZEN-HOPKIN, 2005. 109.o.
} 
volt, hogy ne alkalmazzák, tehát hogy megakadályozzák a külső kormánybuktatást.

A törvényhozás feloszlatására az uralkodó jogosult, ez lényegében a kormányfő kezébe helyezi a döntést a parlament feloszlatásáról. (Ha nem a sikertelen kormányfőválasztás miatt történik a feloszlatás, akkor a király a miniszterelnök indítványát mérlegelés nélkül hajtja végre.) Ez a fentiekhez hasonlóan a végrehajtó hatalmat, kiváltképp annak fejét, a miniszterelnököt erősítő szabályozás a spanyol alkotmányos rendszerben.

Az intézményes feltételek összességében Spanyolországban kedvező feltételeket biztosíthatnak egy egyértelmű törvényhozási többség megléte esetén a stabil kormányzás számára.

\subsection{VÁLASZTÁSI RENDSZER}

A spanyol politikai rendszer és a spanyol kormányok stabilitását a nyolcvanas évektől a 2010-es évek közepéig jelentős részben a választási rendszer hatásai alapozták meg.

A spanyol választási rendszer deklaráltan az arányos képviselet elvet követi, a gyakorlatban azonban a többségi rendszerekéhez hasonló eredményekhez vezet - egészen pontosan vezetett 2015-ig.

Az ibériai országban alkalmazott választási szisztéma zárt területi listákra alapul. A területbeosztás az ország provinciái, azaz tartományai alapján történik. Ezen tartományok az 1830-as években kerültek kialakításra napóleoni francia mintára. ${ }^{17} 50$ ilyen tartomány létezik, ezek lakossága jelentős mértékben eltér egymástól. (Némely régió mindössze egyetlen tartományból áll, a nagyobbak több - eltérô népességû - tartományból épülnek föl. $)^{18}$

A Kongresszus létszáma 350 fő, ez oszlik el a tartományok között. ${ }^{19}$

Országos kompenzáció nincs, ez azt jelenti, hogy a tartományi szinten mandátumot nem eredményező szavazatok egyszerűen elvesznek.

Országos jogi küszöb szintén nincsen, tartományi szinten 3\%-ot szükséges elérni az adott pártnak a mandátumszerzéshez. Ez többnyire csak elméleti korlát, mivel a tartományok nagy részében az implicit küszöb

\footnotetext{
${ }^{17}$ HOPKIN, 2009. 378.o.

${ }^{18}$ HOPKIN, 2009. 376-381.o.

19 A szárazföldi Spanyolország területén - a két metropoliszt is magába foglaló tartományok kivételével - 3 és 16 mandátumot adó kerületek vannak, a többség 10 fősnél kisebb. Lásd: HOPKIN, 2009. 379.o.
} 
meghaladja ezt. (A választások többségének tapasztalatai alapján mindössze a két nagyvárost - Madridot, Barcelonát - is magába foglaló tartományokban jelent valódi korlátot ez a küszöb, minden más körzetben ennél nagyobb az implicit küszöb). ${ }^{20}$

Ezek a szabályozások egyrészt az országosan viszonylag kiegyensúlyozottan nagy támogatottsággal rendelkező pártoknak kedveznek, illetve azon erőknek, melyek egy-egy tartományban, illetve területi választókerületben tudnak jelentős számú szavazatot gyújteni. Kifejezetten nem kedvez ez a rendszer az országosan jelen levő, potenciálisan viszonylag egyenletes támogatottsággal rendelkező középpártoknak. ${ }^{21}$ Ők a főként vidéki kisebb választókerületekben rendszerint nem tudják a magas implicit küszöböket átlépni, ennek következtében mandátumszerzési esélyeik a nagyobb - főként nagyvárosi - tartományokból képzett választókerületekre redukálódnak, ami alulreprezentálja őket az egyes kitüntetett régiókban komoly regionális támogatottsággal jelen levő, azonban az egész országra levetítve mindössze csekélynek tekinthető bázissal rendelkező pártokhoz képest.

\subsection{PÁrtszerkezet}

A pártrendszer alapvető vonásai nagyrészt két tényezőnek köszönhetően alakultak ki. Az egyik az első részben említett regionális rendszer (illetve a régiók közötti politikai szempontú különbségek), a másik pedig az előző részben áttekintett választási rendszer.

Az első tényező hatásai miatt szükséges röviden bemutatni a régiók közötti (párt)politikai szempontú különbségeket.

A pártrendszerre való hatás alapján háromféle régióra különíthetô el a 17 régió. A régiók jelentős részében kizárólag az országos szinten jelen levő erôk esélyesek mandátumhoz jutásra. Ez 2015 előtt azt jelentette, hogy ezen régiókból - illetve a választási rendszer logikájából fakadóan azon tartományokból, melyekből ezek felépülnek - kizárólag a PSOE (Spanyol Szocialista Munkáspárt) és a PP (Néppárt) szerzett mandátumot. A két nagyváros, Barcelona (amely a Katalónia régió részét képező Barcelona tartomány választókörzetébe tartozik) és Madrid (ahol a város az agglomerációval együtt egy régiót is alkotó tartomány része) esetében ezeket

${ }^{20}$ HOPKIN, 2009. 378.o.

${ }^{21}$ Középpártnak a 10 és 20 \% közötti szavazataránnyal rendelkező erőket tekintjük. 
egészíthette ki a radikális baloldali koalíció, ${ }^{22}$ amely ugyan országos szinten szerveződött, $10 \%$ alatti támogatottsága, valamint a vidéki körzetekben érvényesülő magas explicit küszöb miatt, csak itt volt esélye mandátumhoz jutni. ${ }^{23}$

A régiók második csoportját azok alkotják, ahol az előbbiekhez hasonlóan szintén az országos nagy pártok dominálnak, azonban helyi, regionális érdekeket képviselő erők esélyesek 1-2 mandátum szerzésére ezen régiókhoz tartozó körzetekben. A regionális politika szintjén itt szintén a nagy pártok dominálnak, azonban a helyi képviseleti intézmények szintjén állandó, fontos szereplők ezek a regionális pártok. (Ilyenek Aragónia, Galícia, Cantabria, a Kanári-szigetek, illetve Valencia régió.) Ezeknek országos szinten nincs komoly beleszólásuk a politikába, azonban az általuk szerzett mandátumok az invesztitúra folyamata során szerepet játszhatnak (segíthetik, vagy akadályozhatják kisebbségi kormány megalakulását).

A régiók harmadik csoportjába azok tartoznak, ahol önálló, régiós szinten értelmezhető és múködő pártrendszer működik. A Baszk Tartomány és Katalónia, a két, történelmi okokból szeparatista irányzatokkal is bíró régió. Itt a regionális politikai életet a csak ezen tartományokban szerepet vállaló pártok dominálják ${ }^{24}$ (amellett, hogy az országoshoz képest kisebb befolyással, de a nagy pártok is jelen vannak), a nemzeti, spanyolországi szintû választásokon pedig ezek több képviselôvel, létszámarányosan országos kispártként juthatnak komolyabb szerephez. ${ }^{25}$ (Tekintettel arra, hogy ezen régiók választókerületeiből ezek relatíve jelentős mandátumszámhoz juthatnak.) Ez pedig - mint tapasztalható volt 2015 előtt - a mérleg nyelve szerepet biztosította ezen erők számára, releváns párti befolyást az országos, össz-spanyolországi kormányzati erőviszonyokra.

A kettő utóbbi kategória egyfajta keverékét jelenti Navarra, ahol egyaránt komoly erővel vannak jelen az országos pártok, valamint a Baszk Tartomány politikai életét domináló erők is. Az országos megmérettetéseken utóbbiak koalíciókat is köt(het)nek a mandátum-maximalizálás érdekében.

\footnotetext{
22 A Kommunista Pártot is magába foglaló Izquierda Unida - Egyesült Baloldal - névre hallgató pártszövetség.

${ }^{23}$ HOPKIN, 2009. 387.o.

24 SEgura i MaS, 2016. 173.o.

${ }^{25}$ HOPKIN, 2009. 384-385.o.
} 
A spanyol pártrendszert a fenti tényezők következtében két párt dominálta a nyolcvanas évek második felétől a 2015-ös választásokig. Ez a történelmi szociáldemokrata gyökerekkel rendelkező PSOE - Spanyol Szocialista Munkáspárt, valamint az eredetileg a francóista korábbi elitet tömörítő, később egy modernizációs folyamat nyomán a kilencvenes évek elejére jobbközép gyűjtőpárttá váló PP - spanyol elnevezés: Partido Popular Néppárt volt. ${ }^{26}$ Ezek, ahogy fentebb is láthattuk, mind a $17^{27}$ autonóm közösségben, régióban rendelkeznek szervezettel, és országos szinten versengtek a hatalomért.

Spanyolország esetében legkésőbb 1989-től 2015-ig a kétpártrendszer ismérveit ${ }^{28}$ felsoroló feltételek közül a legtöbb fennállt. Két párt versengett a hatalomért, rendszeresen sor került hatalomváltásra, mindig egypárti kormányok alakultak. A Sartori-féle eredeti kétpártrendszer-kategóriától az választja el, hogy nem mindig többségi kormányok alakultak, az időszak jelentős részében egypárti, kisebbségi kormányok múködtek az országban. ${ }^{29}$ A legtöbb forrás - az eltérések csekély volta miatt - „tökéletlen kétpártrendszer" címkét alkalmazza a spanyolországi esetre.

Mivel két párt vetélkedett a kormányzati főhatalomért, ezért megalapozottan állítható, hogy egydimenziós versengés ment közöttük végbe. Ez - leegyszerűsítve - egy alapvetően bal-jobb, gazdaságpolitikai természetú szembenállás volt, ami rendszerstabilizáló hatású. ${ }^{30}$

\section{A KORMÁNYZATI STABILITÁS ALAPSTRUKTÚRÁJA 2015 ELŐTT}

Az egyes választások után 1982 és 2015 között minden esetben kétséget kizáróan megállapítható volt a győztes párt, a potenciális kormányalakító erő. A választási rendszer többségi hatása következtében vagy abszolút többséget szerzett az adott párt (1982, 1986, 1989, 2000,

\footnotetext{
${ }^{26}$ LiNZ-MONTERO, 1999. 38.o.

${ }^{27}$ Formálisan létezik Katalán Szocialista Párt - PSC is, ez azonban a PSOE-val szoros szövetségben, egy frakcióban múködik országos szinten, politológiai szempontból tehát a helyi szervezetének tekinthető. Hasonló konstrukció működött Navarra régióban a Néppárt és a Navarrai Népi Szövetség között 2008 előtt, azóta utóbbi önálló kispártként - ám gyakran a Néppárttal helyi koalícióban - működik.

28 SARTORI, 2005. 167.o.

${ }^{29}$ GALlagher-LAVER-MAIR, 2011. 221.o.

${ }^{30}$ LINZ-MONTERO, 1999. 65.o.
} 
2011), vagy egyértelmű volt, hogy külső támogatással egypárti, kisebbségi kormány tud alakulni. ${ }^{31}$

A külső támogató fél - az esetleges 1-2 fős képviselettel rendelkező kisebb regionális erők mellett - a „lojális” katalán, vagy baszk erők ${ }^{32}$ közül került ki. ${ }^{33}$ Ök tették lehetôvé a kisebbségi kabinetek megalakulását és túlélését a kormányzati ciklusokban (1993, 2004 és 2008 esetében a PSOE kormányai, 1996-ban pedig a Néppárt kormánya). A kormányalakítás során támogatást biztosítottak (vagy a kormányfő megszavazásával, vagy pedig a szavazástól való távolmaradással), kormányba azonban nem mentek be, a támogatás mögött kialakult alkukörnyezetben pedig helyi, regionális vonatkozású érdekeik érvényesítésének segítését kapták az aktuális kormánypártoktól. ${ }^{34}$ Fontos megjegyezni, hogy ezek a külső támogató erők minden esetben csak bizonyos régiókban múködő, azaz nem országos szinten szerveződő pártok voltak.

A 2015-ig terjedő, viszonylag stabil kormányzati, politikai viszonyrendszernek tehát a többségihez hasonló hatású, országos nagy pártokat jutalmazó választási rendszer, illetve a regionális érdekeket képviselő, a spanyol államisághoz alapvetően lojális pártok támogató magatartása volt az előfeltétele.

Ennek a stabilitásnak a következők voltak az alapvető jellegzetességei: ciklusközbeni kormányváltásra egyáltalán nem került sor, egy adott cikluson belül az egypárti kormányok miniszterelnökei kitöltötték mandátumukat. Többciklusos kormányzás volt az általánosan megszokott: 1982 és 1996 között Felipe González szocialista kormányai, 1996 és 2004 között José María Aznar néppárti kabinetjei, a 2004-2011-es periódusban José Luis Rodríguez Zapatero PSOE-s kormányzata, amelyet 2011 után Mariano Rajoy (PP) kormányzása követett.

$\mathrm{Az}$ általános stabilitás formális feltételeit gyengíti, hogy Spanyolországban többször is sor került előrehozott választásra, a ciklus lerövidítésére.

A választások előre hozása azonban nem feltétlen ahhoz kötődött, hogy a kormány elvesztette volna a törvényhozási többségét, vagy úgy ítélte

\footnotetext{
31 VAN BIEZEN-HOPKIN, 2005. 110.o.

32 Katalán részről általában ide tartoztak a CiU - Konvergencia és Unió - választási koalíció tagjai (a liberális Katalán Demokrata Konvergencia és a kereszténydemokrata Katalán Demokratikus Szövetség), baszk részről pedig az EAJ-PNV, a Baszk Nemzeti Párt.

${ }^{33}$ FIELD, 2014. 309.o.

34 AJENJO, 2015. 161-162.o.
} 
volna meg, hogy a közvéleményben tapasztalható bizalomvesztés következtében szükséges a választásokat előre hozni. A választások előrehozására Spanyolországban több esetben kifejezetten taktikai okokból (1986-ban, ${ }^{35}$ illetve 1989-ben) ${ }^{36}$ került sor. A kormány tényleges bukásából, vagy kormányválságból következő idő előtti választás 1993-ban, ${ }^{37} 1996$ ban, ${ }^{38}$ illetve 2011-ben ${ }^{39}$ volt.

Mint az intézményes viszonyok kapcsán látható volt, a gyakorlatban a törvényhozás feloszlatását a kormányfő kezdeményezheti, így ez az ő személyes eszközeként is múködik a választások időpontjának a kormánypárt számára kedvező szituációban való tartására.

\section{A STABILITÁS 2015 UTÁNI MEGRENDÜLÉSÉNEK FŐBB TÉNYEZŐI}

Spanyolország a 2008-as gazdasági válság, majd az azt követő euróválság egyik legkomolyabb kárvallottja volt, a gazdasági visszaesés, illetve az ehhez kapcsolódó társadalmi problémák az átlagosnál jobban érintették az ibériai országot. ${ }^{40} \mathrm{~A}$ pártrendszert is érintő válsághelyzet hosszabb lefolyású volt, sem a közvetlenül a pénzügyi válság során lezajló 2008-as választáson, sem az akkori balközép kormány bukását eredményező, 2011-es előrehozott megmérettetésen nem érvényesült. (Ekkor az alternatív kormánypárt tudta az elégedetlenséget becsatornázni, abszolút többségre szert téve.) 2015-re azonban teljesen új képlet alakult ki.

2015 decemberében már négy olyan országos párt vált esélyessé mandátumszerzésre, amelyek közül kettő még vagy nem létezett a megelőző - de már a válságot követő - választásokon, vagy jelentéktelennek tekinthető helyi szereplőnek bizonyult.

A két új országos szinten is értelmezhetô párt (a radikális baloldali Podemos $^{41}$ - „Képesek vagyunk rá” - mozgalom, valamint a jobboldali liberális mezőbe sorolható Ciudadanos - „Állampolgárok” - névre hallgató

\footnotetext{
35 IPU ARCHIVE (1.)

36 IPU ARCHIVE (2.)

37 VAN BIEZEN-HOPKIN, 2005. 118.o.

38 IPU ARCHIVE (3.)

39 IPU ARCHIVE (4.)

40 Ld. Carballo-Cruz, 2011., Gallagher-Laver-Mair, 2011. 223.o., valamint López GARCIA, 2016.

${ }^{41}$ LÓPEZ GARCIA, 2016.
} 
párt) a végeredményt tekintve a két korábban domináló szereplő kárára volt képes megerősödni. Mindkét szereplő - igaz egész más logikával - a korábbi politikai elit, és vezető pártok kritikusaként lépett színre. ${ }^{42}$

2015-ben és utána a négy országos releváns párt jelenléte teljesen megváltoztatta a választási rendszer múködését. Mivel az új országos pártok befutása és erősödése együtt járt a korábbi pártok jelentős gyengülésével, ezért immáron négy erô volt képes potenciálisan a választási körzetek nagy részében mandátumot szerezni. Ezek az elnyert mandátumok arányát értelemszerűen radikálisan átalakították. ${ }^{43}$

A 2015-re kialakult, immáron négyszereplőssé (a korábban is jelen levő baloldali radikális csoportosulás ezt követően a Podemossal kereste a szövetségkötést) váló országos politikában megszűnt a korábbi automatizmus, amely alapján választásról választásra egyértelmú volt a győztes párt kiléte, amely azután egyedül alakított kormányt. ${ }^{44}$

2015 decemberében az a helyzet állt elő, hogy az akkor megkezdett ciklusban egyáltalán nem volt képes új kormány megalakulni és bizalmat kapni, végig ügyvezetőként maradt hivatalban Rajoy első kormánya. A válsághelyzet feloldására kiírtt ${ }^{45}$ következő nyári (június 26.) választások után is csak hónapokkal később sikerült a konzervatív kormányfőnek bizalmat kapni, azt követően, hogy a szocialista párt időközben súlyos belső válságon ment keresztül, ami lélegzetvételhez juttatta a jobboldalt. ${ }^{46}$

A 2016-os II. Rajoy-kormány azért volt a mögötte álló támogatói kört tekintve innovatív, mert az első olyan alkalom volt, hogy egy kisebbségi kormányt nem csak regionális párt támogatott, hanem országos erő is, az Állampolgárok nevű formációval kötött megállapodás következtében. ${ }^{47}$ Koalícióról mindazonáltal ekkor sem volt szó, összetételében ez egy egypárti kisebbségi kormány volt.

Az országos pártszerkezetben történt komoly átalakulás mellett a másik fontos, az instabilitást erősítő tényező volt Spanyolország politikatörténetében a katalán szeparatizmus erősödése ${ }^{48}$, amely egyrészt az egész országot megrázó, 2017. október 1-jén megtartott, az spanyolországi

\footnotetext{
${ }^{42}$ LÓPEZ GARCIA, 2016. 94., SIMÓN, 2016. 493.o.

43 A választási eredményeket lásd: CONSUlta DE REsulTAdos ElECTORALES 2015.

44 SIMÓN, 2016. 497-498.o.

45 SIMÓN, 2016. 505.o.

46 DíEZ, 2016., JONES, 2016., SiMÓN, 2016. 512.o.

${ }^{47}$ Hedgecoe, 2016.

48 SEGURA I MAS, 2016. 175-176.o.
} 
jog által teljes mértékben illegitimnek tekintett függetlenségi népszavazásban kulminálódott, másrészt a katalán politikai elit radikális függetlenségpárti fordulatában manifesztálódott. Ez utóbbi azt jelentette, hogy azok a katalán erők, amelyek korábban kívülről támogatták az akár bal, akár jobboldali kormányokat, váltak a leginkább függetlenségpártivá, ${ }^{49}$ szembefordulva a teljes össz-spanyolországi elittel. ${ }^{50} \mathrm{Ez}$ amellett, hogy az ország egységét és múködését alapvetően fenyegető fejlemény volt, értelemszerűen jelentősen rontott a kormányzati stabilitás feltételein is, hiszen egy korábban a kormányokat támogató, 10-15 fôs frakcióval ${ }^{51}$ működő erôrôl van szó.

A parlamentarizmus nemzetközi történelme szempontjából is jelentős dátum volt 2018. június elseje, amikor is elsőként került alkalmazásra a konstruktív bizalmatlansági indítvány intézménye egy bizalmat vesztett kormányzat tényleges megbuktatása céljából.

Ezt az eszközt egy olyan belpolitikai környezetben használták, amikor egyáltalán nem jött létre alternatív kormányzati többség. Rajoy kormányát egy korrupciós botrány miatt buktatták meg, a Kongresszus többsége csupán a korrupcióval megvádolt néppárti kormányfő megbuktatásának igényében egyesült. ${ }^{52}$ Rajoy ellenlábasai megszavazták az indítványt, ez azonban az intézmény lényegéből következően automatikusan maga után vonta egy új, a PSOE elnöke, Pedro Sánchez által alakított kormány megválasztását is. Ez a korábbiakhoz hasonlóan egypárti kisebbségi kormány volt, azonban rendkívül törékenynek bizonyult, hiszen a PSOE-nak mindössze 84 képviselője volt a 350 fős Kongresszusban.

Ez önmagában hordozta a bármikori bukás veszélyét, ami bő fél éven belül be is következett.

\subsection{KÉT VÁLASZTÁS 2019-BEN}

A költségvetés bukása vezetett a 2019. április 28-ra kiírt választásokhoz. ${ }^{53} \mathrm{Az}$ áprilisi választás mintegy utólagos megerôsítésként

49 A CiU szövetség felbomlott, az azokat egykor alkotó pártok táborának meghatározó része a függetlenség egyoldalú kinyilvánítása mellett álló, a CiU voltaképpeni utódszervezeteként létrejövő Együtt Katalóniáért blokkhoz csatlakozott. Lásd: CATALANNEWS, 2017.

50 CuAdras-Morató, 2017.

51 A szerző saját gyűjtése, a Kongresszus hivatalos forrásaiból (Gongreso de los Diputados) kinyert adatok alapján.

52 TORRES, 2018.

53 JONES, 2019., TORRES, 2019. 
szolgált a szocialista miniszterelnök és kormánya számára, tekintettel, hogy 2011 tele óta elsőként tudták legyőzni a Néppártot az országos törvényhozási választáson. A parlamenten belül megszerzett kormányzási lehetôség tehát társadalmi többséggé is konvertálódott, azonban ez csak relatív többség lett, hiszen a párt szavazataránya még a 2011-es elvesztett választásokhoz képest is kisebb lett $(28,68 \%$, a 28,76\%-hoz képest). Amellett, hogy jelentôsen tudták a 2015-16-os választásokhoz képest a választói támogatottságukat növelni, a szocialisták számára a győzelem mértéke főként a Néppárt történelmi mértékủ bukásának (1989-es létrejötte óta először kapott 25\%-nál kevesebb - mindössze 16,7\%-nyi szavazatot) köszönhető. ${ }^{54}$

A politikai paletta általános áttekintése kapcsán látható, hogy nemcsak, hogy megmaradt a 2015-'16-ban is már meghatározó négy erő, hanem csatlakozott hozzájuk az erőteljesen nacionalista, nemzeti jobboldali alakulat, a Vox is országos pártként.

A balközép párt egyértelmú relatív győzelme ellenére ez a szavazás is lényegében inkonkluzív választás ${ }^{55}$ lett. Ez determinálta a bizonytalanságot a későbbi kormányalakítás kapcsán is. Míg 2016-ban végül a jobbközép erők közti megállapodás vezetett kormányalakításhoz, 2019 tavaszán erre a baloldalnak lett lehetősége (123 szocialista és 42 Podemos-szövetséghez tartozó képviselő volt ekkor, azaz egy relatív többséggel bíró kormány megalakításának előfeltétele volt a két nagyobb baloldali erő közötti megállapodás). A szövetségkötés elsőre a formális koalícióban való egyet nem értés miatt bukott el. Míg a Podemos ragaszkodott volna a koalíciós kormányzáshoz, a PSOE az ország hagyományai alapján ${ }^{56}$ külső támogatást várt volna el. 2016-hoz hasonlóan így ismételten új választás kírásával próbálkoztak feloldani a válsághelyzetet, melyet 2019. november 10-re tűztek ki.

\footnotetext{
${ }^{54}$ A választási eredményeket lásd: CONSULTA DE RESUltados ELECTORALES 2019a.

$55 \mathrm{Az}$ angol nyelvű nemzetközi sajtó azon esetekre használja ezt a kifejezést, ahol nem egyértelmű a korábban megszokott minták alapján a következő kormányzat felállása és összetétele.

56 A kormányokat korábban támogató regionális erôk jellemző módon a saját régiójukat érintő ügyek támogatásáért cserébe adtak támogatást, nem merült föl az, hogy az országos kormányzati politika egészét ne egyetlen párt határozza meg.
} 
A 2019-es éven belüli második választás nem eredményezett jelentős átrendeződéseket a politikai erők versenyében, a korábbi bizonytalanság prolongálódását jelentette a választás. ${ }^{57}$

A legjelentősebb változás az országos pártok erősorrendje tekintetében a Ciudadanos megroppanása volt, amivel párhuzamosan a Néppárt csekély mértékben visszaerősödött az áprilisi történelmi veresége után, illetve a Vox további erősödése. A fó átrendeződés tehát a jobboldali pártok eredményének megoszlásában volt.

A megismétlődő patthelyzet ellenére - a társadalom türelmének elvesztésétól tartva (aminek a jele a részvételi arány 5\%-os csökkenése is volt) - a politikai erôk az új választások után már kompromisszumkésznek bizonyultak. Ez a korábban elvetett koalíciós megoldás elfogadását jelentette, amelyben Sánchez Szocialista Pártja tett lényegi engedményt, az eddig ismeretlen formula elfogadásával. A két baloldali párt összefogása sem volt elegendő azonban a törvényhozásban a többség eléréséhez, mivel a két pártnak együttesen is csak 155 képviselője volt (az első körben szükséges 176-hoz képest). Ezt a korábban egyébként megszokottnak tekintett gyakorlatnak megfelelően a regionális erők bevonásával kívánták elérni, a helyzet azonban az elhúzódó katalán válság miatt bonyolultabb volt, mint a korábbi kormányalakítások során.

Mindazonáltal a korábbi évtizedekben radikálisabbnak számító, 2017 után azonban tárgyalóképesebbnek tekinthető Köztársasági Baloldal (ERC) felé tett kompromisszumos lépések segítették hozzá a PSOE-Podemos koalíciót a beiktatáshoz szükséges szavazatok megszerzéséhez a kormányalakításkor általában konstruktívnak tekinthetô további kis regionális pártokat reprezentáló képviselők megnyerése mellett. ${ }^{58}$

Így, a spanyolországi invesztitúra-szabályozásnak megfelelően, a második körben elegendő volt a relatív többség biztosítása a Kongresszusban a PSOE-Podemos koalíciós kormánynak, amely 2020. január 13-án hivatalba tudott lépni.

57 CONSUlta de Resultados Electorales 2019b.

58 BAQUERO, 2020. 


\section{KONKLÚZIÓ}

A kormányzati stabilitás korábban tapasztalható mintázatainak összeomlását Spanyolországban több tényező együttes hatása okozta.

A változás egyik oka, hogy az intézményrendszer csak bizonyos társadalmi-politikai erőviszonyok rendelkezésre állásával volt képes a stabilitást biztosítani. A stabilitást erősítő intézményes megoldások megteremtik a lehetôséget a stabil kormányzásra, ha van egy működőképes kormánytöbbség a törvényhozásban. Utóbbihoz azonban vagy az szükséges, hogy egy párt képes legyen abszolút többségre szert tenni, vagy pedig legyen koalíciós, és/vagy együttmúködési potenciál a releváns erők között.

Hasonlóképpen érvényesült a választási rendszer szerepe. Az országos szinten „kvázi kétpártrendszerként” értelmezhető pártrendszer kialakulását és múködését biztosító szisztéma új, országos szinten is releváns, a választókerületekben meglévő implicit küszöbök átlépésére is képes erők megjelenése esetén már nem volt képes a korábbi „szưrő” funkciót ellátni, így további erők országos szintű megjelenése is lehetséges volt.

Mivel 2015 előtt nem volt szükség az ilyen jellegű együttmúködésekre, ezért Spanyolországban nem alakult ki országos szinten a koalíciós kormányzásnak hagyománya. Ez pedig a legutóbbi négy választás utáni pártközi tárgyalások tanulságait vizsgálva egyértelmúen megnehezítette az új politikai környezethez való alkalmazkodást a politikai elit fóbb szereplőinek részéről. Látható, hogy a korábban domináló két párt ebben az időszakban mindenképpen a lehető legvégsőkig törekedett a koalíciókötés elkerülésére.

Speciális, a spanyolországi viszonyokat egyedi jelleggel befolyásoló tényezőként érvényesült a regionális önállósági törekvéssel bíró Katalónia esete. Jóllehet, a többi tényező hatásaként mindenképpen instabillá vált volna a spanyolországi belpolitika, a katalán függetlenedési törekvések időbeni egybeesése még inkább megrendítette a stabil kormányzás alapjait az országban.

Spanyolország példája egy nagyobb európai trendbe tűnik beleillőnek. Írország (2016, 2020), Svédország (2018), Hollandia (2017), illetve már Németország (2017) legutóbbi választásai is azt mutatják, hogy a korábbi évtizedekben megszokott kormányalakítási mintáknak megfelelően már nem képesek a törvényhozásba kerülő erők többségi, működőképes kormányt létrehozni.

Spanyolország tekintetében az évtizedek óta első koalíciós kormány megalakulása mindenképpen korszakhatárt jelent, az 1970-es évek vége óta 
tartó kétpárti váltógazdálkodást mutató korszak lezárultát. Az új koalíciós minta mûködőképessége mindazonáltal tanulságos lehet egy tágabb európai kontextusban is.

\section{FELHASZNÁLT IRODALOM}

Könyvek, tanulmányok

Ajenjo, Natalia (2015): Why Minority Governments in Spain? How the Party System Undermines Investiture Rules. In Parliaments and Government Formation eds.: Rasch, Bjørn - Erik, Martin - Shane, Cheibub, José Antonio; Oxford University Press. DOI azonosító: 10.1093/acprof:oso/9780198747017.001.0001

CARBallo-CruZ, Francisco (2011): Causes and Consequences of the Spanish Economic Crisis. In Panoeconomicus, 2011, 3. pp. 309-328. DOI azonosító: 10.2298/PAN1103309C

FIELD, BONNIE N. (2014): Minority Parliamentary Government and Multilevel Politics - Spain's System of Mutual Back Scratching. In Comparative Politics April 2014 pp. 293-312.

Gallagher, Michael, Michael Laver, Peter Mair (2011): Representative Government in Modern Europe, McGraw-Hill Education, Maidenhead, Berkshire

HebBert, Michael (1987): Regionalism: a Reform Concept and its Application to Spain. In Environment and Planning C: Government and Policy, 1987, vol. 5. DOI azonosító: https://doi.org/10.1068/c050239

HOPKIN, JONATHAN (2009): Spain: Proportional Representation with Majoritarian Outcomes. In The Politics of Electoral Systems eds.: Gallagher, Michael, Mitchell, Paul Oxford University Press. DOI azonosító: 10.1093/0199257566.001.0001

Linz, JuAn J., José RAMÓn MONTERo (1999): The Party Systems of Spain:

Old Cleavages and New Challenges. Estudio/Working Paper 1999/138 June

LÓPez Garcia, Guillermo (2016): A Spanish „Yes, We Can!” Against the Two-Party System: The Development of Political Party Podemos. Anali Hrvatskog politološkog društva 201613 (1) pp. 83-99

SARTORI, GIOVANNI (2005): Parties and Party Systems - A Framework for Analysis, ECPR Press 
Segura i Mas, Antoni (2016): The End of the Two-Party System of Spain? IE Med. Mediterranean Yearbook pp. 172-176

SIMÓN, PABLO (2016): The Challenges of the New Spanish Multipartism:

Government Formation Failure and the 2016 General Election. South European Society and Politics, 21:4, pp. 493-517 DOI azonosító: https://doi.org/10.1080/13608746.2016.1268292

TÓTH LÁSZLÓ (2018): A kormányzati stabilitást befolyásoló intézményes viszonyok Kelet-Közép-Európában. In Tavaszi Szél 2018 Tanulmánykötet szerk.: Keresztes Gábor, Budapest, Doktoranduszok Országos Szövetsége.

VAN BIEZEN, IngRID, JONATHAN HopkIn (2005): The Presidentialization of Spanish Democracy: Sources of Prime Ministerial Power of PostFranco Spain. In The Presidentialization of Politics eds.: Poguntke, Thomas - Webb, Paul Oxford University Press.

WARWICK, PAUL (1994): Government Survival in Parliamentary Democracies. Cambridge University Press

Választási eredmények

Consulta de Resultados Electorales (2015):

http://www.infoelectoral.mir.es/min/busquedaAvanzadaAction.html?vuelt $\underline{a}=1 \& \operatorname{cod}$ TipoEleccion $=2 \& \operatorname{codPeriodo}=201512 \& \operatorname{cod} E \operatorname{stado}=99 \& \operatorname{codC}$ omunidad $=0 \&$ codProvincia $=0 \& \operatorname{codMunicipio}=0 \& \operatorname{codDistrito}=0 \& \operatorname{codS}$ eccion $=0 \&$ codMesa $=0$ (letöltve: 2020 . április 9.)

CONSUlta DE RESUlTAdos Electorales (2019a - Apr):

http://www.infoelectoral.mir.es/min/busquedaAvanzadaAction.html?vuelt $\underline{a}=1 \& \operatorname{cod}$ TipoEleccion $=2 \& \operatorname{codPeriodo}=201904 \& \operatorname{cod} E s t a d o=99 \& \operatorname{cod} \mathrm{C}$ omunidad $=0 \&$ codProvincia $=0 \& \operatorname{codMunicipio}=0 \& \operatorname{codDistrito}=0 \& \operatorname{codS}$ eccion $=0 \&$ codMesa $=0$ (letöltve: 2020. április 9.)

CONSUlta de Resultados Electorales (2019b - Nov):

http://www.infoelectoral.mir.es/min/busquedaAvanzadaAction.html?vuelt $\underline{a}=1 \& \operatorname{cod}$ TipoEleccion $=2 \& \operatorname{codPeriodo}=201911 \& \operatorname{codEstado}=99 \& \operatorname{codC}$ omunidad $=0 \&$ codProvincia $=0 \& \operatorname{codMunicipio}=0 \& \operatorname{codDistrito}=0 \& \operatorname{cod} S$ $\underline{\text { eccion }=0 \& \operatorname{codMesa}=0}$ (letöltve: 2020 . április 9.)

A Kongresszus honlapja

CONGRESO DE LOS DipUTADOS. Letöltés helye: 
http://www.congreso.es/portal/page/portal/Congreso/Congreso

Az Inter-Parlamentáris Unió Archívuma

IPU ARCHIVE (1.). Letöltés helye: http://archive.ipu.org/parlinee/reports/arc/SPAIN 1986 E 2.PDF (letöltve: 2020. április 20.)

IPU ARCHIVE (2.) Letöltés helye: http://archive.ipu.org/parlinee/reports/arc/2293 89.htm (letöltve: 2020. április 20.)

IPU ARCHIVE (3.) Letöltés helye: http://archive.ipu.org/parlinee/reports/arc/2293 96.htm (letöltve: 2020. április 20.)

IPU ARCHIVE (4.) Letöltés helye: http://archive.ipu.org/parlinee/reports/arc/2293 11.htm (letöltve: 2020. április 20.)

Hivatkozott újságcikkek

Baquero, Camilo S. (2020): Catalan separatists give green light to new Socialist government in Spain, El País

https://english.elpais.com/elpais/2020/01/03/inenglish/1578040105 633

743.html (letöltve: 2020. április 9.)

CatalanNews (2017): Puigdemont to head 'Together for Catalonia' https://www.catalannews.com/politics/item/puigdemont-to-headtogether-for-catalonia (letöltve: 2020. április 9.)

Cuadras-Morató, Xavier (2017): 3 ways the election changed Catalan politics, Politico https://www.politico.eu/article/3-ways-electionchanged-catalan-politics/ (letöltve: 2020. április 9.)

DíEZ, ANABEL (2016): Spain's two main parties finally start talking to each other, $\mathrm{El}$

País https://english.elpais.com/elpais/2016/10/07/inenglish/1475824590 6 38103.html (letöltve: 2020. április 9.)

HedgeCoE, GuY (2016): Albert Rivera's Faustian bargain https://www.politico.eu/article/albert-riveras-faustian-bargain-rajoycatalonia-socialist-ciodadanos-spain-elections/ (letöltve: 2020. április 9.)

Jones, SAM (2016): Mariano Rajoy sworn in as Spain's PM after deadlock broken, The

Guardian https://www.theguardian.com/world/2016/oct/31/mariono-rajoy-tobe-sworn-in-as-spains-prime-minister (letöltve: 2020. április 9.) 
JONES, SAM (2019): Spain's opposition parties demand snap election after budget rejection, The Guardian https://www.theguardian.com/world/2019/feb/13/spanish-pm-pedrosanchez-snap-general-election-budget (letöltve: 2020. április 9.)

TORRES, DiEgo (2018): Spain's Rajoy ousted in no confidence vote, Politico https://www.politico.eu/article/spains-rajoy-ousted-in-noconfidence-vote/ (letöltve: 2020. április 9.)

Torres, Diego (2019): Spain's Sanchez calls snap election, Politico https://www.politico.eu/article/spains-sanchez-calls-snap-election-onapril-28/ (letöltve: 2020. április 9.) 